\title{
EFFICIENT MAXIMUM POWER POINT ESTIMATION MONITORING OF PHOTOVOLTAIC USING FEED FORWARD NEURAL NETWORK
}

\author{
Hasnira, Novie Ayub Windarko, Anang Tjahjono, Mochammad Ari Bagus Nugroho, Mentari \\ Putri Jati \\ Politeknik Elektronika Negeri Surabaya \\ Kampus PENS Jl. Raya ITS Sukolilo, Surabaya, 60111 \\ e-mail : rhara@polibatam.ac.id, ayub@pens.ac.id, anang@pens.ac.id, aribagusnugroho@gmail.com, \\ mentaripj@gmail.com
}

\begin{abstract}
Abstrak
Perkembangan pemanfaatan panel surya di masa depan akan terus meningkat. Salah satu bentuk karakteristik panel surya merupakan kurva I-V yang mana dengan kurva tersebut dapat digunakan untuk menganalisa besaran daya keluaran panel surya. Dengan mengetahui kurva I-V tersebut dapat dilakukan Maximum Power Point Estimation (MPPE) yang dapat diampu oleh panel surya. Informasi mengenai nilai estimasi daya maksimum panel surya merupakan bagian penting untuk menentukan kapasitas pembebanan, selain itu juga untuk menjaga umur peralatan yang digunakan. Feed Forward Neural Network dengan Algoritma Back Propagation (FFBP) terbukti dapat memberikan informasi nilai MPPE pada keluaran panel surya. Nilai masukan pada ANN berupa tegangan dan arus dari panel surya, sedangkan keluaran dari ANN tersebut berupa nilai estimasi daya. Hasil dari simulasi MPPE didapatkan galat rata rata sebesar 0.04 poin antara daya aktual (MPP) dan daya estimasi (MPPE).
\end{abstract}

Kata kunci: Solar panel, Maximum Power Point, Artificial Neural Network

\begin{abstract}
The development of the utilization of solar panels in the future will continue to increase. One characteristic form of solar panels is the I-V curve which can be used to analyze the amount of solar panel output power. By knowing the I-V curve, we can get Maximum Power Point Estimation (MPPE) value that can be supported by solar panels. Information about the estimated value of the maximum solar panel power is an important part in determining the loading capacity, while maintaining the life of the equipment used. Feed Forward Neural Network with Back Propagation Algorithm (FFBP) has proven to be able to provide MPPE value information on solar panel output. The input values in ANN are the voltage and current of the solar panel, while the output of ANN is in the form of an estimated power value. MPPE simulation results obtained an average error of 0.04 points between actual power (MPP) and estimated power (MPPE).
\end{abstract}

Keywords: Solar panel, Maximum Power Point, Artificial Neural Network

\section{Introduction}

Kebutuhan energi masa depan akan semakin besar sesuai dengan keberlanjutan pertumbuhan ekonomi berdasarkan dari penelitian BPPT (Badan
Pengembangan dan Pengkajian Teknologi) [1]. Pembangkitan energi terbesar didominasi oleh energi tak terbarukan seperti bahan bakar fosil yang menyebabkan pencemaran udara dan masalah masalah lingkungan [2], [3]. Untuk mengimbangi hal 
tersebut, pemanfaatan energi surya menjadi topik utama yang sedang dikembangkan berbagai negara karena termasuk energi terbarukan dan ramah lingkungan.

Panel surya memiliki karakteristik I-V tidak linier, merupakan peralatan yang umum dipakai untuk mengubah energi surya menjadi daya listrik [4]. Di sisi lain, daya keluaran panel surya, yang mempunyai efisiensi konversi energi rendah, sangat bergantung pada radiasi matahari, suhu, karakteristik beban dan tegangan panel tersebut. Faktor lingkungan seperti radiasi matahari dan suhu sulit ditentukan secara sistematis. Hal umum pada solar panel yang dibahas oleh peneliti sebelumnya adalah tentang Maximum Power Point Tracking (MPPT). MPPT mencari titik maksimum dari kurva karakteristik daya- tegangan $(P-V)$ serta kurva arus-tegangan ( $I-V)$ pada panel surya, diharapkan daya output akan selalu berada pada kondisi maksimum. Sedangkan maximum Power Point Estimation (MPPE) yang dihasilkan oleh panel surya merupakan hal yang harus diperhatikan selain dari MPPT. Maka, penting untuk mengadakan pengendalian daerah operasi ketersediaan daya maksimum atau Maximum Power Point (MPP) pada pemanfaatan panel surya.

MPPE dilihat berdasarkan dari besaran daya tertinggi yang mana nilai pasti tidak diketahui selama implementasi sebenarnya. Penerapan metode MPPE dapat menjaga umur peralatan sampai jangka waktu yang relatif lama. Informasi MPPE juga dibutuhkan dalam proses integrase panel surya ke sistem microgrid. Beberapa jenis algoritma yang digunakan untuk melacak nilai MPPE seperti Pesturb and Observe (P\&O), dan Increment Conductance (IC) [5]-[7]. Algoritma - algoritma ini mempunyai karakteristik tersendiri termasuk kurang akurat, waktu komputasi rendah, kebutuhan sensor, adanya osilasi, sifat konvergensi, kurang responsif, informasi parameter masukan, dan efektifitas minimal [8]-[10].

Untuk mengoptimalkan teknik MPPE tersebut, terdapat suatu metode terbarukan dengan hasil akurat, cepat, ilmiah, dan tidak membutuhkan informasi parameter internal, yang mana metode untuk memperkirakan nilai MPP tersebut menggunakan Artificial Neural Network (ANN) [11]-[14]. Proses learning ANN dapat menentukan karakteristik panel surya yang secara tidak langsung memperkirakan posisi MPPE dari panel surya. Kelebihan ANN lainnya yaitu memiliki respon kecepatan tinggi, ketahanan operasi, sedikit komputasi dan dapat dijadikan solusi untuk masalah yang multi variabel [15], [16]. Selain itu, sistem monitoring secara tepat MPP panel surya juga penting untuk memastikan peralatan beroperasi dengan lancar [17].

Dalam makalah ini membahas metode ANN dengan menggunakan algoritma feed foward back propagation untuk mendapatkan nilai MPPE yang mana hasil kerja panel surya sesungguhnya bergantung dari kondisi radiasi matahari. Monitoring hasil MPPE panel surya akan ditampilkan pada PC dengan koneksi wireless yang efisien dan mudah berdasarkan implementasi hardware sebenarnya.

\section{Studi Pustaka}

\section{A. Pemodelan panel surya}

Panel surya berfungsi untuk merubah radiasi matahari menjadi energi listrik. Cara pemasangan panel surya bisa dilakukan secara seri maupun paralel. Sistem karakteristik panel surya mampu menghasil kurva I-V dan P-V yang non linier. Semua disebabkan oleh perubahan suhu dan radiasi yang ada pada saat itu. Rangkaian ekuivalen panel surya ini diwakili oleh satu sumber arus, satu dioda yang terhubung paralel dengan sumber arus, satu resistor yang terhubung paralel dengan sumber arus dan diode, satu resistor seri, dan terminal keluaran. Daya yang dihasilkan oleh masing masing sel tergantung pada titik operasi sepanjang kurva I-V, suhu, iradiasi, dan teknologi pembuatan panel surya. Pemodelan panel surya umumnya menggunakan model satu dioda ataupun dua diode. Dalam penelitian ini menggunakan model konvensional satu dioda dengan pemodelan seperti pada gambar 1 berikut ini.

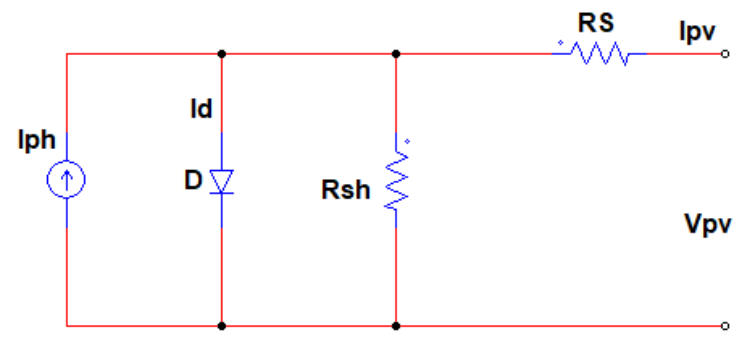


Gambar 1. Pemodelan panel surya satu dioda

Gambar 1 adalah rangkaian ekuivalen dari model satu dioda. Sumber arus akan terhubung secara paralel dengan dioda dan resistor paralel serta serangkain resistor yang terhubung dibagian terminal output [18]. Berdasarkan model satu diode, karakteristik I-V panel surya dirumuskan dengan (1).

$I_{p v}=I_{p h}-I_{S}\left(e^{\frac{V_{p v+I}+I_{s} R_{s}}{n N_{S} V_{t}}}-1\right)-\frac{V_{p v}+I_{p v} R_{S}}{R_{S h}}$

Di mana, $I_{p v}$ dan $V_{p v}$ adalah arus dan terminal tegangan pada panel surya, $I_{p h}$ adalah arus yang dihasilkan ketika panel surya terkena iradiasi matahari, $I_{s}$ adalah arus jenuh, $n$ adalah faktor kualitas diode, $N_{s}$ adalah jumlah solar sel terhubung ke satu panel, $V_{t}$ adalah tegangan termal sel surya, serta $R_{s h}$ dan $R_{s}$ adalah paralel dan seri resistor panel surya. Arus yang dihasilkan oleh $I_{p h}$ sepenuhnya bergantung pada radiasi matahari yang dipaparkan oleh panel surya sehingga dapat disajikan pada Persamaan (2).

$I_{p h}=\frac{G}{1000}\left(I_{s c}+K_{i}\left(T-T_{r}\right)\right)$

Dengan $I_{p h}$ adalah arus hubung singkat dari panel surya, $G$ adalah nilai iradiasi matahari $\left(\mathrm{W} / \mathrm{m}^{2}\right)$, $T_{r}$ adalah suhu sel surya, dan $K_{i}$ adalah koefisien suhu arus hubung singkat.

\section{B. Radiasi Matahari}

Tegangan output panel surya tidak terlalu terpengaruh terhadap cahaya matahari. Namun arus keluar sangat terpengaruh oleh intensitas cahaya matahari yang jatuh diatas permuakaan panel surya. Dengan terpengaruhnya arus keluar terhadap intensitas cahaya, ini berarti efisiensi kerja dari panel surya sangat dipengaruhi oleh intensitas cahaya matahari. Hal ini terlihat pada Gambar 2 yang merupakan karakteristik dari arus dan tegangan terhadap intensitas cahaya matahari. Terlihat bahwa tegangan tidak terpengaruh, namun arus akan terpengaruh yaitu ketika intensitas cahaya turun maka arusnya kecil dan saat intensitas cahaya naik maka arus akan bertambah besar.

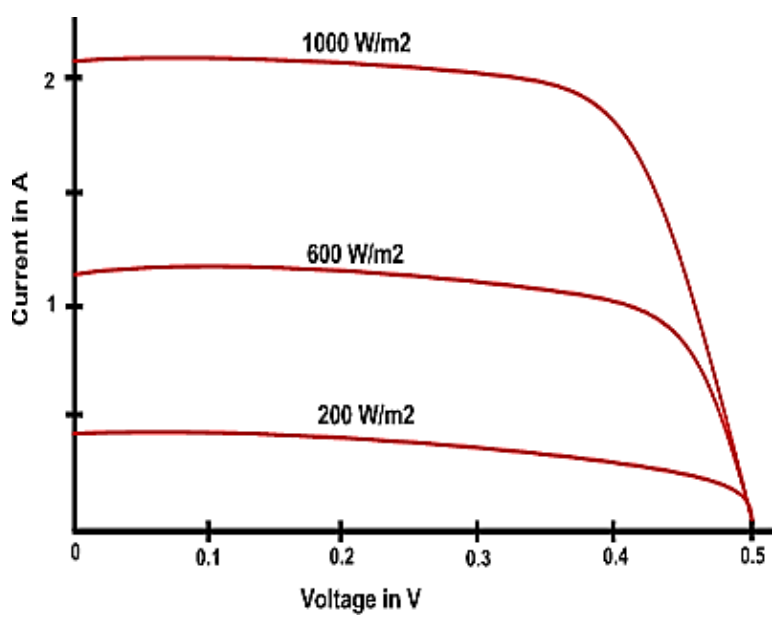

sumber: Ika W, Rancang Bangun Sistem Penggerak Pintu Air dengan Memanfaatkan Energi Alternatif Matahari, PENS - ITS, hal. 24.

Gambar 2. Karakteristik Arus dan Tegangan Terhadap Pengaruh Intensitas Cahaya Matahari.

Dari Gambar 1 dan Gambar 2 memiliki sebuah keterkaitan yaitu pada Iph pada Gambar 1 dan karakteristik arus pada Gambar 2. Semakin besar nilai iradiasi maka karakteristik Iph akan semakin besar, dan semakin kecil iradiasi, karakteristik Iph akan semakin kecil. Sedemikian hingga, Iph sebagai sumber arus ini dapat disimulasikan dengan menggunakan power supply sebagai penyedia arus. Simulasi panel surya dapat dilakukan dengan biaya murah dan dapat menyamai karakteristik panel surya pada kondisi iradiasi yang bervariasi. Simulator dapat bekerja tanpa tergantung lingkungan, khususnya iluminasi buatan atau sinar matahari. Simulator panel surya terdiri atas panel surya dan power supply DC [sitasi Simulator Panel Surya Ekonomis untuk Pengujian MPPT pada Kondisi Berbayang Sebagian]. Teknik simulasi panel surya dengan menggunakan power supply ini dapat dikatakan dengan teknik simulasi unilluminated panel surya.

Teknik unilluminated dilakukan dengan cara memposisikan panel surya pada area yang gelap (umumnya panel surya dihadapkan ke permukaan lantai atau meja) sehingga dapat dipastikan tanpa ada cahaya yang diterima panel surya, $\mathrm{Iph}=0$. Secara karakteristik panel surya tidak mengeluarkan daya karena $\mathrm{Iph}=0$. Namun sesuai dengan Gambar 1, model dari panel 
surya terdapat diode, resistor shunt dan resistor seri tetap ada sebagai elemen dasar dari model panel surya. Sehingga dengan menambahkan sumber arus eksternal dari power supply DC dapat digunakan untuk menggantikan Iph dan memvariasikan Iph. Sesuai dengan karakteristik Ipv pada Persamaan (1), bahwa Ipv sangat bergantung dengan Iph. Sehingga dengan menggantikan arus Iph dengan power supply DC, maka karaktersitik panel surya yang sesungguhnya dapat dibangkitkan. Sehingga simulasi panel surya dengan teknik unilluminated (tanpa cahaya) dapat dilakukan untuk pengujian teknik MPPE yang diajukan dalam makalah ini.

\section{Arsitektur Artificial Neural Network}

Artifical Neural Network (ANN) merupakan sistem komputasi yang arsitektur dan pengoperasiannya dilatarbelakangi oleh pengetahuan tentang sel syaraf biologis didalam otak. ANN merupakan salah satu representasi buatan dari otak manusia yang selalu mencoba menstimulasi proses pembelajaran pada otak manusia tersebut. Gambar 3 dibawah ini merupakan arsitektur ANN yang umum digunakan.

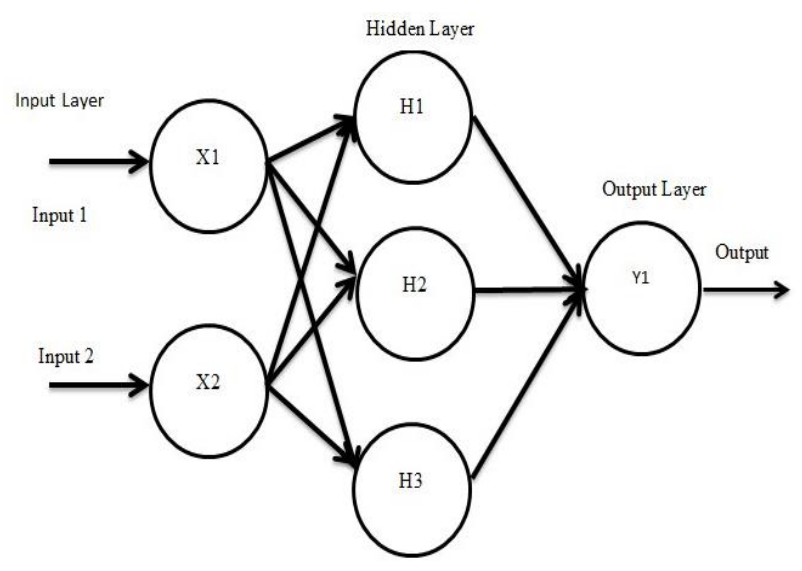

Gambar 3. Arsitektur Neural Network

Feed Forward Back Propogation adalah arsitektur yang digunakan. Terdiri dari tiga layer yaitu bagian input yang merupakan tempat data yang sudah diambil, hidden layer adalah tempat dimana data diproses, dan output layer adalah hasil [19]. Dalam pemodelan ANN MPP, data pembelajaran menggunakan data tegangan dan arus, ANN akan mengestimasikan output dalam bentuk kurva prediksi daya maksimum persatuan waktu yang ditentukan nantinya. bentuk kurva prediksi daya maksimum ini yang nantinya akan digunakan sebagai referensi dalam mengoptimasi perhitungan beban maksimum yang dapat dibebani pada sistem panel surya.

Untuk pengujian arsitektur ANN menggunakan sofware MATLAB. Nilai tegangan (V), arus (I) dan daya (P) yang sudah didapatkan dari hasil simulasi menggunakan sofware PSIM dijadikan sebagai referensi yang akan di training oleh ANN. Nilai tegangan dan arus keluaran dari solar panel akan menjadi masukan (input) dalam arsitektur ANN, sedangkan keluarannya (output) dari ANN adalah nilai daya.

Ada banyak parameter yang harus diperhatikan pada saat menggunakan metode Artificial Neural Network $(A N N)$. Seperti pemilihan jumlah layer, hidden neuron, epoch dan nilai Means Squared Error (MSE) terkecil. Dari parameter ANN yang didapatkan, maka akan mampu menghasilkan nilai daya estimasi yang paling menyerupai dengan nilai aktualnya. Adapun cara menentukan jumlah hidden neuron adalah dengan menggunakan persamaan 3 sebagai berikut ini [20]:

$\mathbf{h n}=\sqrt{\mathbf{i n}+\mathbf{o n}}+\mathbf{\sigma}$

dimana:

$\boldsymbol{h n}=$ Hidden neuron

in = input layer

on=output layer

nilai $\sigma$ adalah antara 1 hingga 10

\section{Metode}

Penelitian ini bertujuan untuk memberikan estimasi Maximum Power Point Estimation (MPPE) dari panel surya. 


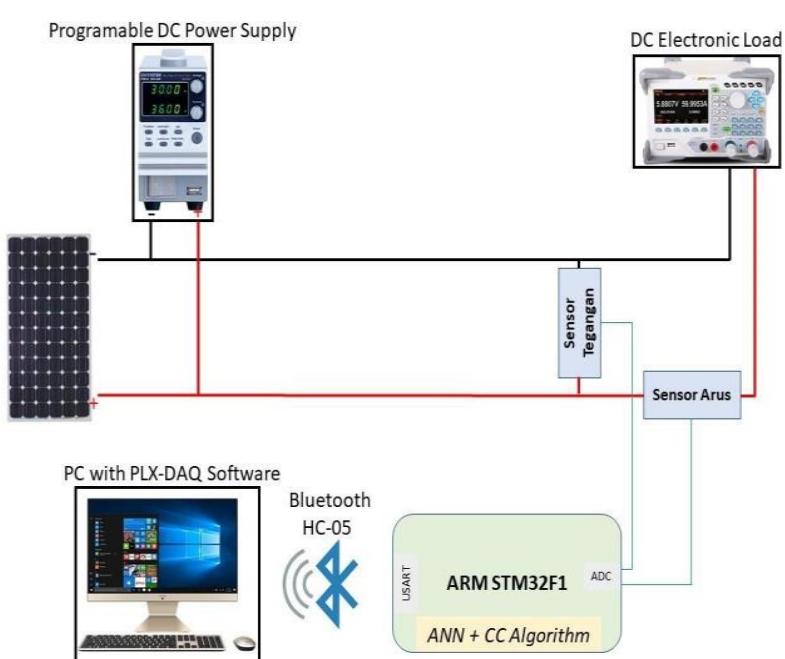

Gambar 4. Blok diagram system

Gambar 4 diatas menjelaskan bahawa DC power supply sebagai sumber tegangan dc digunakan sebagai sumber listrik oleh panel surya. Selanjutnya sensor tegangan dan arus keluaran dari panel surya akan diambil informasinya dan dianggap sebagai data referensi masukan dari input layer Artificial Neural Network $(A N N)$. Dengan menggunakan satu unit dummy load sebagai bebannya. Mikrokontroller ARM STM32F1 akan mengolah data tegangan dan arus dari solar panel sebagai nilai Maximum Power Point Estimation (MPPE), selanjutnya data tersebut akan dikirimkan ke perangkat computer (PC) dengan menggunakan serial komunikasi Bluetooth type HC-05. Untuk proses training ANN menggunakan sofware Matlab, kemudian akan menghasilkan laporan output nilai daya yang dilaporkan dalam bentuk format file excel. Pada sistem ini terdapat Solar PV dengan daya 100WP dan beban resitance berupa dummy load sebesar $15 \mathrm{~K} \Omega 200$ Watt. Beberapa hal yang dilakukan dalam pengujian ini adalah:

1. Pemodelan menggunakan sofware Power SIM (PSIM).

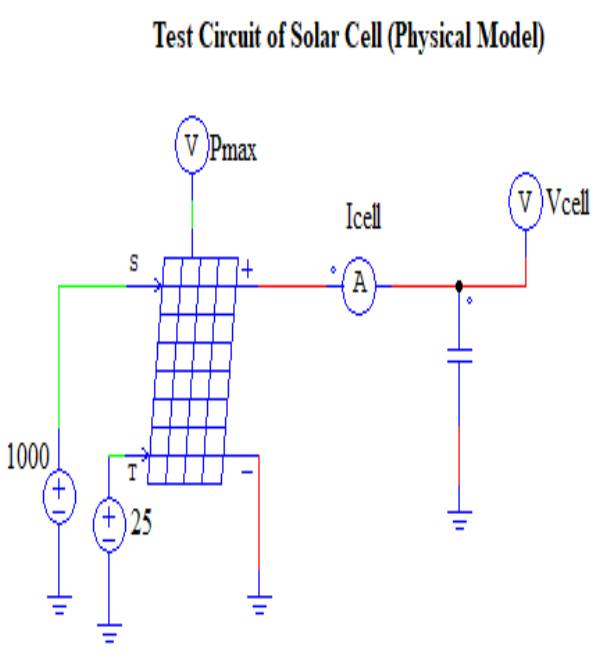

Gambar 5. Simulasi Solar Panel

Gambar 5 terlihat bahwa pada simulasi ini dilakukan pengambilan data tegangan $(\mathrm{V})$, arus (A) dan daya (P) dari panel surya dengan nilai iradiasi yang berbedabeda. Pada simulasi ini didapatkan koleksi data sebesar 50.000 data per satu nilai iradiasi.

\section{Pengukuran data secara Unilluminated}

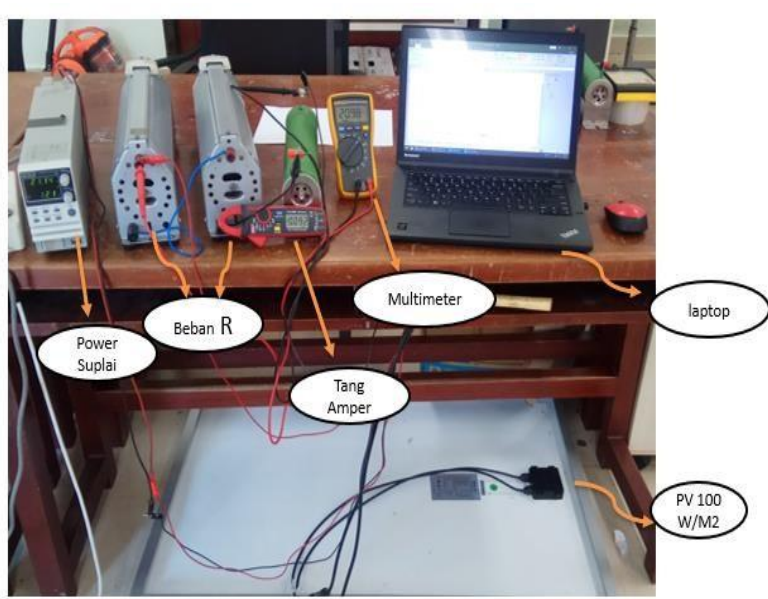

Gambar 6.Alat pengujian solar panel secara Unilluminated

Permintaan untuk sistem pembangkit listrik energi surya terus meningkat karena adanya peningkatan panel surya dan teknologi konversi daya, terutama dengan meningkatnya permintaan untuk energi terbarukan di seluruh dunia. Sejumlah besar listrik solar panel sekarang disuntikkan ke dalam sistem utilitas melalui jaringan distribusi. Simulasi sumber daya Solar panel 
dibuat menggunakan Solar panel yang tidak diberi cahaya (Unilluminated Solar panel) dan diparalel menggunakan sumber arus untuk menguji solar inverter dan algoritma MPP dilaboratorium. Selain melakukan simulasi dengan PSIM dan mengolah data dengan ANN. pengukuran secara manual juga dilakukan dengan metode uniluminated untuk mengehtahui nilai keluar baik pada tegangan maupun arus dari solar panel. Gambar 6 diatas adalah rakitan alat uji yang untuk mendapatkan nilai tegangan, arus dan daya.

Dalam pengujian ini spesifikasi solar panel yang digunakan dapat terlihat pada tabel 1 berikut.

Tabel 1. Spesifikasi Solar Panel

\begin{tabular}{|l|l|}
\hline Maximum Power (Pmax) & $100 \mathrm{~W}$ \\
\hline $\begin{array}{l}\text { Maximum Power Voltage } \\
\text { (Vmp) }\end{array}$ & $17.6 \mathrm{~V}$ \\
\hline $\begin{array}{l}\text { Maximum Power Voltage } \\
\text { (Imp) }\end{array}$ & $5.69 \mathrm{~A}$ \\
\hline $\begin{array}{l}\text { Open Circuit Current } \\
\text { (Voc) }\end{array}$ & $22.6 \mathrm{~V}$ \\
\hline $\begin{array}{l}\text { Short Circuit Current } \\
\text { (Isc) }\end{array}$ & $6.09 \mathrm{~A}$ \\
\hline
\end{tabular}

Karakteristik panel surya yang ditunjukkan pada Tabel 1 didapatkan dari nameplate panel surya yang tertera pada bagian belakang panel surya. Setiap panel surya memiliki karakteristik yang berbeda-beda sesuai desain fabrikasi dari panel surya. Spesifikasi yang tertulis pada nameplate panel surya diuji pada kondisi iradiasi $1000 \mathrm{Watt} / \mathrm{m}^{2}$ dan suhu $25^{\circ} \mathrm{C}$.

Nilai Isc dan Voc akan menjadi acuan untuk menghasilkan data pengukuran sesuai dengan nilai iradiasi yang diinginkan. Voc merupakan nilai tegangan open circuit yaitu nilai tegangan yang terukur disaat nilai arus sama dengan nol. Berdasarkan dari karakteristik panel surya yang digunakan pada Tabel 1, kapasitas panel surya $100 \mathrm{wp}$, nilai Voc adalah $22.6 \mathrm{~V}$. Sedangkan untuk Isc pada penelitian ini didapatkan dari nilai arus maksimum panel surya. Nilai Isc ini identik dengan nilai Iph pada Persamaan 1, dimana secara nyata, nilai Isc ini dipengaruhi oleh iradiasi matahari yang diterima panel surya. Sehingga dengan melakukan teknik unilluminated yang telah dijelaskan pada bab sebelumnya, dapat dilakukan pengujian simulasi variasi iradiasi dengan memvariasikan arus Iph menggunakan power supply DC. Dalam pengujian ini dilakukan pendekatan nilai arus Iph memiliki hubungan linier terharap iradiasi. Sehingga dengan mengatur arus power supply DC sebagai pengganti Iph, berarti bahwa telah mensimulasikan perubahan iradiasi yang diterima panel surya. Tabel 2 merupakan data acuan karakteristik panel surya yang digunakan untuk mendapatkan data data referensi V, I dan $\mathrm{P}$ yang kemudian akan di trainingkan dengan Artificial Neural Network (ANN).

Tabel 2. Acuan nilai untuk pengukuran secara Uniluminated dari PV type $100 \mathrm{~W} / \mathrm{m}^{2}$

\begin{tabular}{|c|l|l|l|}
\hline No & \multicolumn{1}{|c|}{ Iradiasi } & \multicolumn{1}{|c|}{ Voc $(\mathbf{V})$} & \multicolumn{1}{|c|}{ Isc (A) } \\
\hline 1 & 1000 & 22.6 & 6.09 \\
\hline 2 & 900 & 22.6 & 5.481 \\
\hline 3 & 800 & 22.6 & 4.872 \\
\hline 4 & 700 & 22.6 & 4.263 \\
\hline 5 & 600 & 22.6 & 3.654 \\
\hline 6 & 500 & 22.6 & 3.045 \\
\hline 7 & 400 & 22.6 & 2.436 \\
\hline 8 & 300 & 22.6 & 1.827 \\
\hline 9 & 200 & 22.6 & 1.218 \\
\hline 10 & 100 & 22.6 & 0.609 \\
\hline
\end{tabular}

Dari Tabel 2, dapat diketahui bahwa perubahan iradiasi hanya berdampak pada perubahan pengaturan Isc pada power supply. Hal ini sangat berkaitan dan sesuai dengan Gambar 2 yang menyatakan mengenai grafik karakteristik panel surya, bahwa perubahan iradiasi yang diterima panel surya akan berdampak pada perubahan nilai arus hubung singkat panel surya.

\section{Pembelajaran menggunakan Artifcial Neural Network (ANN).}

Setelah didapatkan nilai data referensi berupa tegangan dan arus, maka hal selanjutnya melakukan pembelajaran menggunakan ANN. Dengan menggunakan arsitektur ANN sebagaimana yang terlihat pada gambar 7 dibawah ini. 


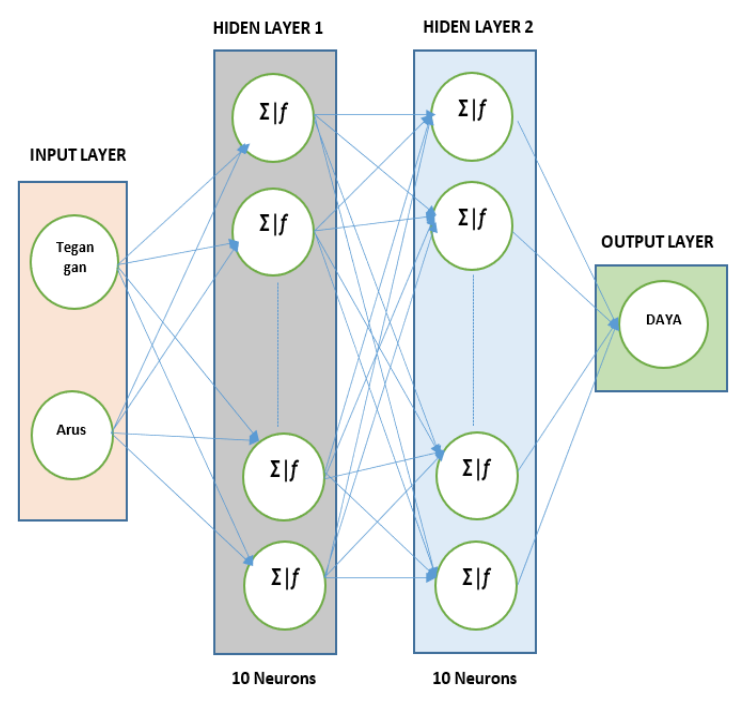

Gambar 7. Arsitektur Artificial Neural Network yang digunakan.

Pada proses seperti gambar 7 diatas, input yang diambil sebagai referensi data akan diolah kembali untuk mencari hasil estimasi keluaran daya. Pada penelitian ini digunakan 2 nilai input yaitu tegangan dan arus, pengujian dengan 2 hidden layer, 10 jumlah neuron dan satu nilai output yang merupakan nilai daya estimasi.

Hasil dari training ANN selain memperhatikan nilai regression, hal terpenting lainnya adalah nilai error (MSE). Eror terkecil merupakan nilai terbaik untuk sebuah proses pembelajaran menggunakan neural network. Sedangkan epoch merupakan satu siklus pembelajaran penuh untuk data yang sudah ditentukan. Atau dengan kata lain jumlah epoch adalah hyperparameter yang menentukan berapat kali algoritma pembelajaran akan berkerja mengolah seluruh dataset training. Dalan jaringan saraf tiruan, proses pembelajaran yang berulang-ulang bertujuan untuk mencapai konvergensi nilai bobot. Karena nilai epoch yang sesuai tidak bisa diketahui, maka pada penelitian ini diujikan beberapa nilai epoch untuk mencapai nilai akurasi yang optimum. Dan nilai epoch yang diuji adalah 1000 .

\section{Hasil dan Pembahasan}

Pada bagian ini menjelaskan tentang hasil MPPE yang sudah diuji. Baik dengan menggunakan data yang bersumber dari Power SIM (PSIM) maupun hasil dari pengukuran uniluminated solar panel.

\section{Simulasi PSIM}

1.1 Hasil pengujian pada 1 iradiasi (iradiasi 100).

Pada iradiasi 100, terdapat 50.000 data yang akan di olah oleh ANN. Dengan menggunakan metode Feed Foward Back Propogation (FFBP). Untuk mencari nilai neuron terbaik tersebut didapatkan berdasarkan hasil penggunaann pada rumus 3 sebelumnya. berdasarkan dari percobaan dengan membandingkan MSE, hidden neuron dan epoch didapatkan hasil sebagai tabel 3 berikut ini.

Tabel 3. Data hasil pengujian iradiasi 100

\begin{tabular}{|l|l|l|l|l|l|}
\hline No & $\begin{array}{l}\text { Hidden } \\
\text { layer }\end{array}$ & $\begin{array}{l}\text { Hidden } \\
\text { Neuron }\end{array}$ & MSE & $\begin{array}{l}\text { Regressi } \\
\text { on }\end{array}$ & Epoch \\
\hline 1 & 1 & 3 & 0.0099435 & 0.99958 & 1000 \\
\hline 2 & 1 & 4 & 0.0015094 & 0.99993 & 1000 \\
\hline 3 & 1 & 5 & 0.0010297 & 0.99995 & 1000 \\
\hline 4 & 1 & 6 & 0.0036724 & 0.99998 & 1000 \\
\hline 5 & 1 & 7 & 0.0001413 & 0.99999 & 1000 \\
\hline 6 & 1 & 8 & $3.63 \mathrm{E}-05$ & 1 & 1000 \\
\hline 7 & 1 & 9 & $3.82 \mathrm{E}-05$ & 1 & 1000 \\
\hline 8 & 1 & 10 & $9.39 \mathrm{E}-06$ & 1 & 1000 \\
\hline 9 & 1 & 11 & $2.00 \mathrm{E}-05$ & 1 & 1000 \\
\hline 10 & 1 & 12 & $7.95 \mathrm{E}-06$ & 1 & 1000 \\
\hline
\end{tabular}

Pada tabel terlihat bahwa 1 hidden layer dan neuron 12 merupakan nilai terbaik yang memiliki nilai MSE terkecil dan regression 1.

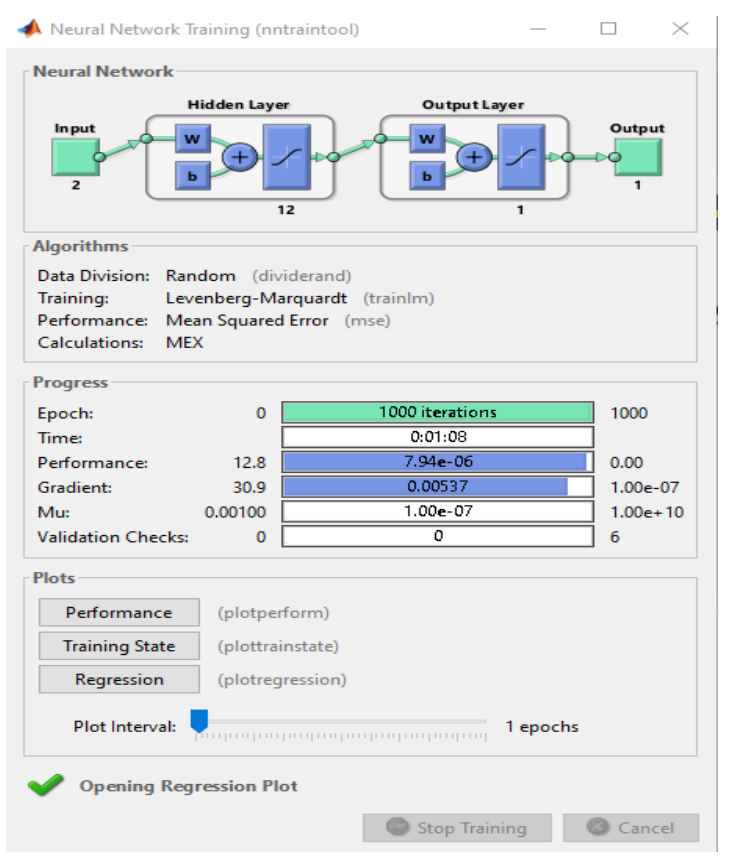

Gambar 8. hasil training MPPE pada iradiasi 100 
Pada gambar 8 merupakan arsitektur Feed Forward Neural Network dengan algoritma Backpropagation (FFBP). Dan gambar 9 merupakan hasil regression setelah dilakukan training untuk menentukan nilai MPPE. Dari hasil training dapat dilihat kinerja ANN sangat bagus. nilai target daya yang hendak diprediksi sesuai dengan hasil data simulasi. Hasil dari regression ANN baik training, validation, test maupun target bernilai 1 atau $100 \%$.

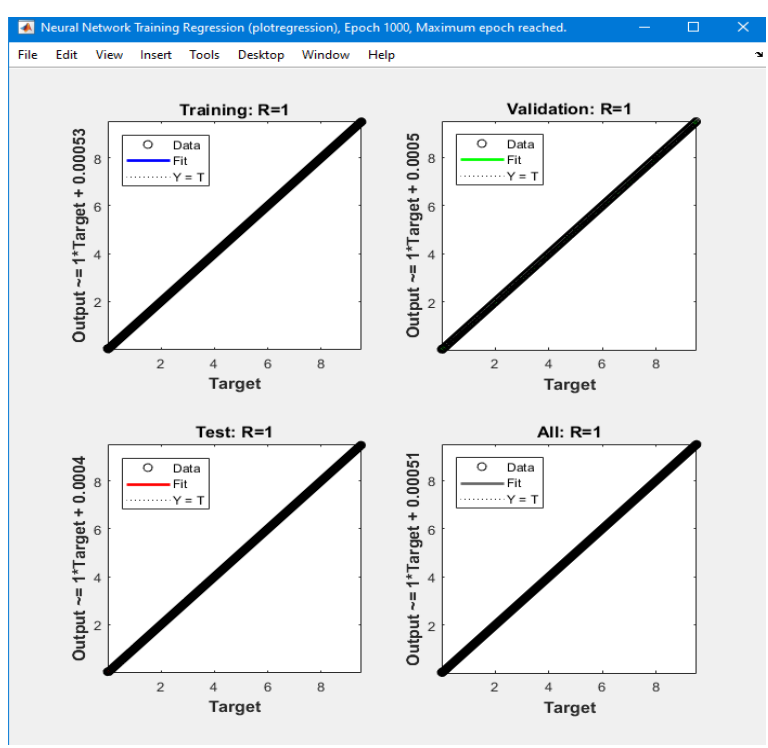

Gambar 9. Hasil Regression Untuk Estimasi MPP Pada Iradiasi 100

Selanjutnya untuk membuktikan hasil pengolahan training ANN tersebut dapat menggunakan sofware simulink seperti yang terlihat pada gambar 10 berikut ini.

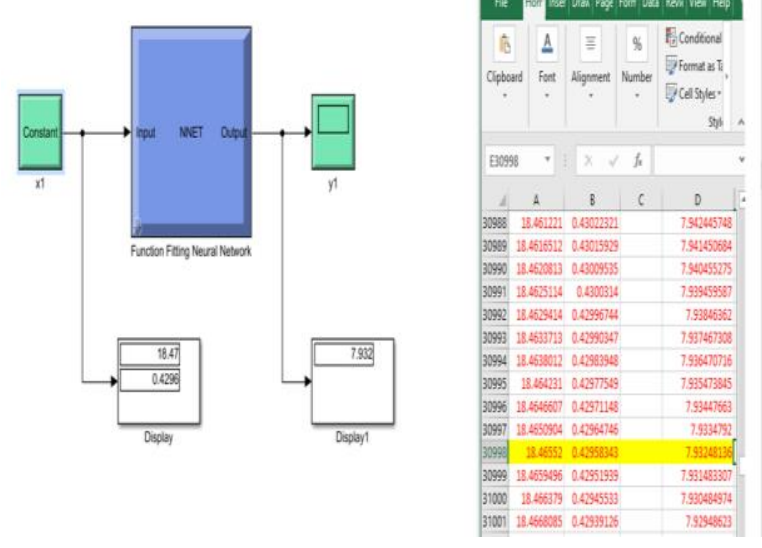

Gambar 10. Pengujian Simulink data iradiasi 100
Data excell bagian kanan merupakan nilai yang didapatkan dari pengujian PSIM. Data tersebut akan dibandingkan dengan hasil simulink disebelahnya. Terlihat gambar 10 diatas yaitu apabila simulink yang merupakan model setelah dilakukan training ANN dimasukkan nilai input V dan I maka hasil output daya estimasi akan ditampilkan. Dimana nilai input untuk gambar pertama simulink tegangannya $(\mathrm{V})=18.46552$ volt, arus $(\mathrm{I})=0.42958343$ ampere, dan daya $(\mathrm{P})=$ 7.93248136 watt. Sedangkan Hasil target daya dari simulink berdasarkan hasil pengolahan ANN adalah sebesar 7.932 watt.

Gambar 11 berikut adalah hasil perbandingan antara MPP dan MPPE pada 1 iradiasi (iradiasi 100).

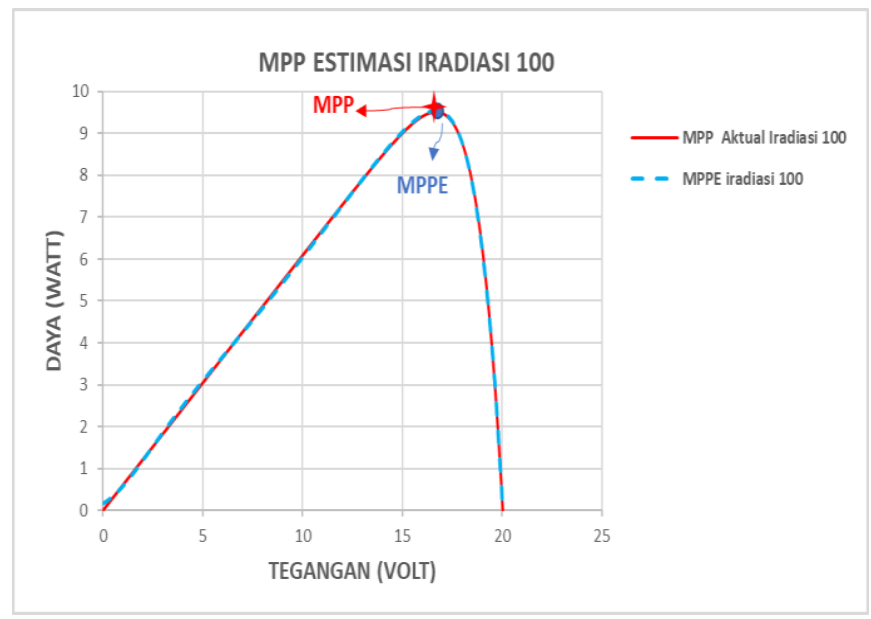

Gambar 11. Kurva MPP dan MPPE pada 1 iradiasi Gambar 11 terlihat hasil pembelajaran ANN untuk mengestimasi nilai MPP. Terlihat antara data aktual dan MPPE tidak ada perbedaan. Secara keseluruhan ANN dengan algoritma FFBP mampu menentukan nilai MPPE.

1.2 Hasil pengujian pada iradiasi 100-500 ( 5 iradiasi).

Pada pengujian ini 5 iradiasi ini, jumlah data yang akan diolah sebanyak 250.000 data masukan yang berupa nilai arus dan tegangan.Setelah melakukan identifikasi data dengan mencari nilai eror terkecil, maka didapatkan hasil pelatihan ANN seperti yang terdapat pada tabel 4 dibawah. Dengan melakukan pengujian menggunakan 1 hidden layer dengan variasi 12 jumlah neuron, maka didapatkan hasil data eror terkecil (MSE) adalah 2.08E-03 dengan nilai regression 0.99999. 
Tabel 4. Data hasil pengujian 5 iradiasi

( iradiasi $100-500$ )

\begin{tabular}{|c|l|l|l|l|l|}
\hline No & $\begin{array}{l}\text { Hidden } \\
\text { layer }\end{array}$ & $\begin{array}{l}\text { Hidden } \\
\text { Neuron }\end{array}$ & MSE & Regression & Epoch \\
\hline 1 & 1 & 3 & 0.41828 & 0.99747 & 1000 \\
\hline 2 & 1 & 4 & 0.40825 & 0.99746 & 1000 \\
\hline 3 & 1 & 5 & 0.031642 & 0.9998 & 1000 \\
\hline 4 & 1 & 6 & 0.01026 & 0.99993 & 1000 \\
\hline 5 & 1 & 7 & 0.015817 & 0.99989 & 1000 \\
\hline 6 & 1 & 8 & $3.74 \mathrm{E}-03$ & 0.99998 & 1000 \\
\hline 7 & 1 & 9 & $3.36 \mathrm{E}-03$ & 0.99998 & 1000 \\
\hline 8 & 1 & 10 & $2.08 \mathrm{E}-03$ & 0.99999 & 1000 \\
\hline 9 & 1 & 11 & $5.19 \mathrm{E}-02$ & 0.99967 & 1000 \\
\hline 10 & 1 & 12 & $4.99 \mathrm{E}-03$ & 0.99997 & 1000 \\
\hline
\end{tabular}

Secara keseluruhan proses learning ANN seperti yang tertera pada Gambar 12-13 dibawah ini.

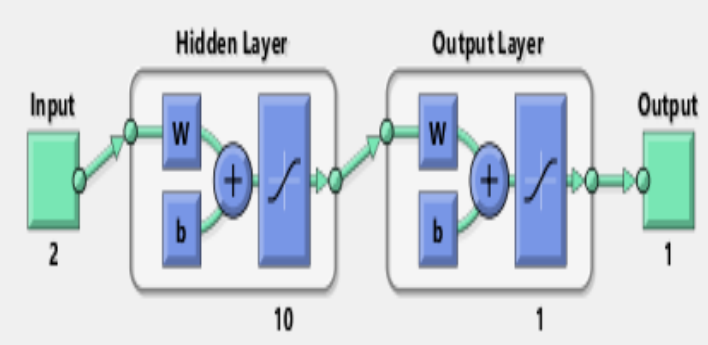

Gambar 12. Arsitektur ANN pada iradiasi 100-500
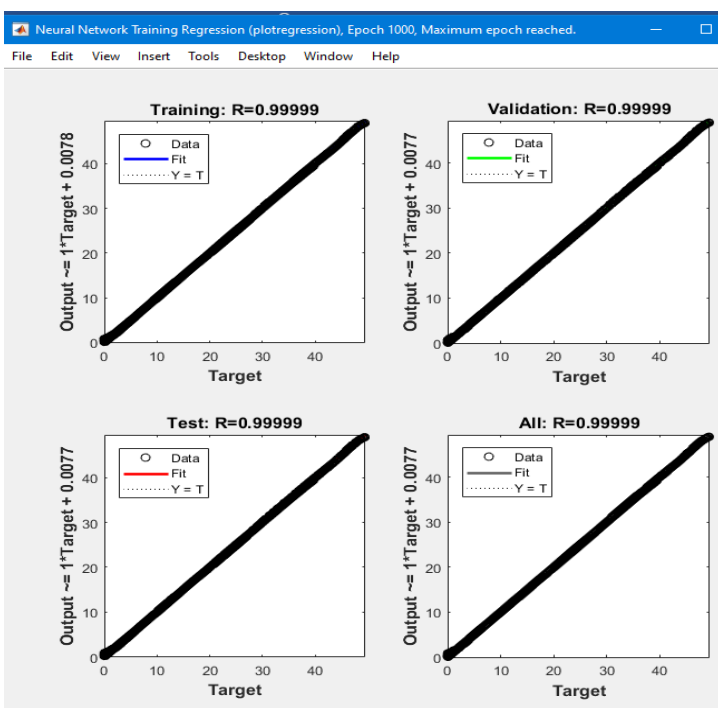

Gambar 13. Hasil Regression Untuk Estimasi MPP

Pada Iradiasi 100 - 500

Gambar 12 merupakan arsitektur dari ANN dengan menggunakan 10 hidden neuorn, sedangkan gambar 13 adalah hasil regression setelah dilakukan pembelajaran oleh ANN. Neural Network ditujukan untuk MPPE dengan input berupa tegangan dan arus. Semua training dalam mendapatkan nilai regression sebagaimana pada Tabel 1 dan Tabel 2 menggunakan command 'nntool' dalam Matlab.

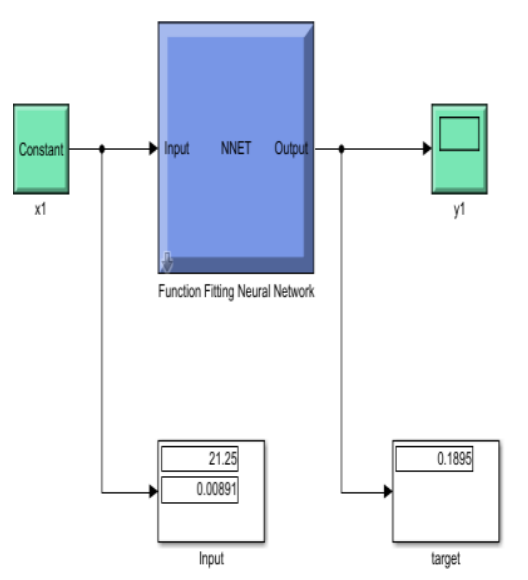

\begin{tabular}{|c|c|c|c|c|c|c|}
\hline \multicolumn{2}{|c|}{ A117024 } & \multicolumn{2}{|c|}{$: x \vee f_{x}$} & \multicolumn{3}{|c|}{ 21.251254784693 v } \\
\hline & A & $B$ & c & D & E & . \\
\hline 117019 & 21.25121 & 0.00895 & & 0.190201 & & \\
\hline 117020 & 21.25122 & 0.008942 & & 0.19003 & & \\
\hline 117021 & 21.25123 & 0.008934 & & 0.189859 & & \\
\hline 117022 & 21.25124 & 40.008926 & & 0.189688 & & \\
\hline 117023 & 21.25125 & 0.008918 & & 0.189517 & & \\
\hline 117024 & 21.25125 & 0.00891 & & 0.189346 & & \\
\hline 117025 & 21.25126 & 50.008902 & & 0.189175 & & \\
\hline 117026 & 21.25127 & 0.008894 & & 0.189004 & & \\
\hline 117027 & 21.25128 & 0.008886 & & 0.188834 & & \\
\hline 117028 & 21.25129 & 0.008878 & & 0.188664 & & \\
\hline 117029 & 21.2513 & 0.00887 & & 0.188494 & & \\
\hline 117030 & 21.25131 & 0.008862 & & 0.188324 & & \\
\hline 117031 & 21.25132 & 20.008854 & & 0.188154 & & \\
\hline 117032 & 21.25133 & 30.008846 & & 0.187984 & & \\
\hline 117033 & 21.25133 & 30.008838 & & 0.187815 & & \\
\hline 117034 & 21.25134 & $\begin{array}{ll}4 & 0.00883\end{array}$ & & 0.187646 & & \\
\hline 117035 & 21.25135 & 50.008822 & & 0.187477 & & \\
\hline $1 / 1136$ & & $010 \times 8 \times 1$ & & 0.187308 & & \\
\hline
\end{tabular}

Gambar 14. Pembuktian estimasi daya di Simulink dari data iradiasi 100-500

Gambar 14 adalah hasil pengujian ANN untuk estimasi nilai dayanya sudah sesuai. Pada simulink nilai masukkan akan dijadikan bilangan bulat. Dimana nilai masukan $\mathrm{V}=21.25$ volt, $\mathrm{I}=0.00891$ Ampere, maka didapatkan hasil target 0.1895 watt. Data excel bagian samping diatas merupakan data hasil simulasi dari PSIM yang ternyata sama dengan hasil pembuktian dengan simulinknya. Dimana nilai daya hasil simulasi adalah 0.189346 watt.

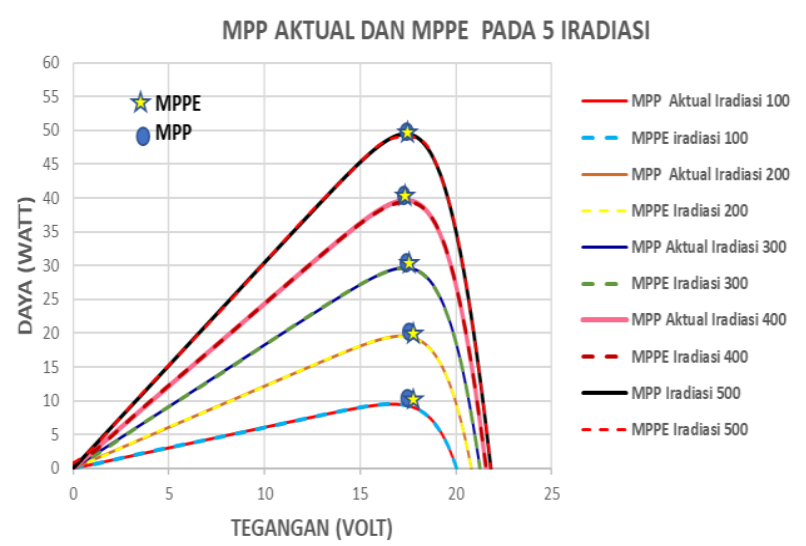

Gambar 15. Kurva MPP dan MPPE pada 5 iradiasi

Gambar 15 berikut dapat membandingakn antara MPP dan MPPE per setiap iradiasi. Secara keseluruhan terlihat hasil antara training ANN dan data yang bersumber dari PSIM sangat mendekati. Dengan 
terestimasinya nilai MPP, maka pengontrolan beban lebih mudah dilakukan dan keselamatan peralatan juga lebih terjaga. Kurva tersebut merupakan gabungan dari 5 nilai iradiasi yaitu iradiasi 100-500. Untuk dapat menghasilkan suatu sistem yang dapat bekerja dengan baik, maka performa panel surya harus selalu beroperasi pada titik Mpp. Dengan mengetahui kondisi daya yang tersedia saat itu, maka tentunya akan dapat mempermudah kita dalam menentukan nilai beban yang sesuai. Sehingga keselamatan peralatan dapat terjaga dan performa kerja maksimal.

\section{Uniluminated Panel Surya}

2.1 Hasil pengujian uniluminated 1 iradiasi ( Iradiasi 100)

Berdasarkan pengambilan data secara uniluminated, dengan menggunakan nilai epoch 1000 didapatkan nilai hasil neuron terbaik seperti pada tabel 5 berikut ini.

Tabel 5. Pengujian Arsitektur ANN pada Iradiasi 100.

\begin{tabular}{|c|c|c|c|r|}
\hline No & $\begin{array}{c}\text { Hidden } \\
\text { Layer }\end{array}$ & $\begin{array}{r}\text { Hidden } \\
\text { Neuron }\end{array}$ & \multicolumn{1}{c|}{ MSE } & Regression \\
\hline 1 & 1 & 3 & 0.021082 & 0.998 \\
\hline 2 & 1 & 4 & 0.036838 & 0.99652 \\
\hline 3 & 1 & 5 & 0.02133 & 0.99809 \\
\hline 4 & 1 & 6 & 0.015858 & 0.99795 \\
\hline 5 & 1 & 7 & 0.016413 & 0.99807 \\
\hline 6 & 1 & 8 & $1.65 \mathrm{E}-02$ & 0.99811 \\
\hline 7 & 1 & 9 & $1.98 \mathrm{E}-02$ & 0.99813 \\
\hline 8 & 1 & 10 & $2.14 \mathrm{E}-02$ & 0.99814 \\
\hline 9 & 1 & 11 & $1.86 \mathrm{E}-02$ & 0.99816 \\
\hline 10 & 1 & 12 & $1.82 \mathrm{E}-02$ & 0.99814 \\
\hline 11 & 2 & 3 & 0.017592 & 0.998 \\
\hline 12 & 2 & 4 & 0.018192 & 0.99801 \\
\hline 13 & 2 & 5 & 0.019946 & 0.99811 \\
\hline 14 & 2 & 6 & 0.0214 & 0.99783 \\
\hline 15 & 2 & 7 & 0.017142 & 0.99821 \\
\hline 16 & 2 & 8 & 0.016222 & 0.99823 \\
\hline 17 & 2 & 9 & 0.014882 & 0.99818 \\
\hline 18 & 2 & 10 & 0.015969 & 0.99827 \\
\hline 19 & 2 & 11 & 0.1616 & 0.99819 \\
\hline 20 & 2 & 12 & 0.013975 & 0.99827 \\
\hline
\end{tabular}

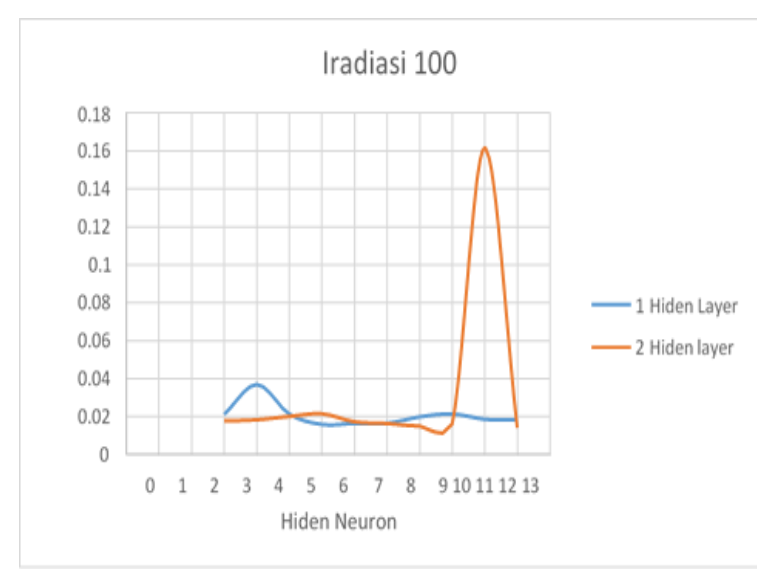

Gambar 16. Kurva Eror terhadap Hidden Neuron pada 1 iradiasi

Error yang dihasilkan berdasarkan training ANN dapat diterlihat pada gambar 16 diatas dimana menggunakan hidden layer 1 jauh lebih baik daripada hidden layer 2 pada training dengan menggunakan epoch 1000 . Apabila dibandingkan dengan tabel 7 nilai error terkecil itu berada di hidden layer 1 dengan jumlah neuron 8 dan memiliki nilai error $1.65 \mathrm{E}-02$ dan reggression 0.99811 .

Untuk memverifikasi hasil pengukuran dan learning ANN, dapat terlihat pada gambar 15 berikut ini.

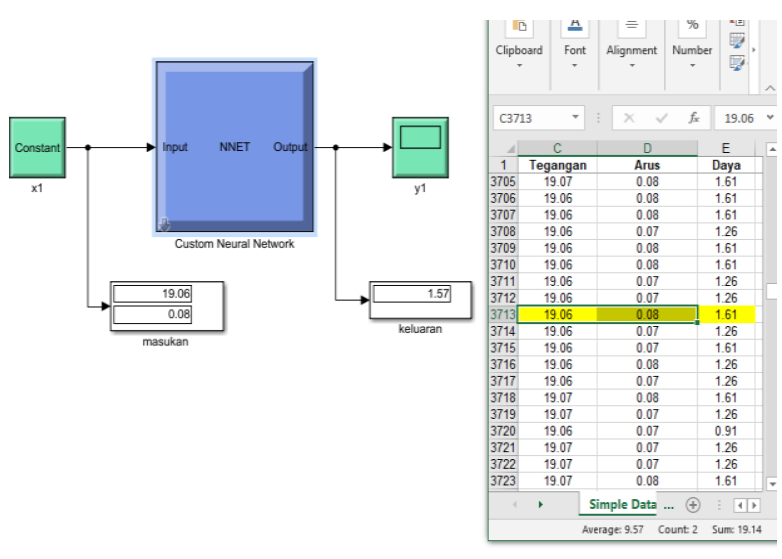

Gambar 17. Hasil pembuktian Simulink dengan menggunakan 1 Hidden Layer dan 8 Neuron

Gambar 15 diatas antara hasil tabel data uniluminated dan simulink terdapat selisih nilai daya antara estimasi dan pengukuran sebesar 0.04 point. Gambar 18 berikut adalah gambar kurva MPPE pada 1 iradiasi. 


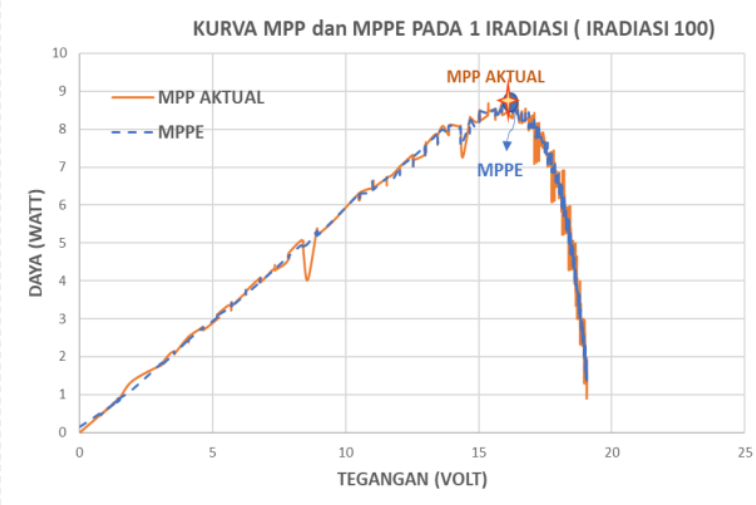

Gambar 18. Kurva MPP dan MPPE pada satu iradiasi

Dari gambar 18 telah dibuktikan bahwa hasil pengukuran yang dilakukan sudah mampu membuat bentuk kurva karakteristik dari panel surya. ANN sudah mampu memprediksi nilai daya sesuai dengan input yang diberikan. Nilai MPPE yang didapatkan pada iradiasi 100 adalah sebesar 8.4 Watt.

\subsection{Hasil pengujian uniluminated 3 iradiasi}

( Iradiasi 100 - 300)

Tabel 6. Pengujian Arsitektur ANN pada Iradiasi 100300 (iradiasi) dengan epoch 1000

\begin{tabular}{|c|c|c|c|c|}
\hline No & $\begin{array}{c}\text { Hidden } \\
\text { Layer }\end{array}$ & $\begin{array}{c}\text { Hidden } \\
\text { Neuron }\end{array}$ & MSE & Regression \\
\hline 1 & 1 & 3 & 0.068504 & 0.99752 \\
\hline 2 & 1 & 4 & 0.045915 & 0.99816 \\
\hline 3 & 1 & 5 & 0.033796 & 0.99865 \\
\hline 4 & 1 & 6 & 0.036086 & 0.9987 \\
\hline 5 & 1 & 7 & 0.033193 & 0.99878 \\
\hline 6 & 1 & 8 & $2.73 \mathrm{E}-02$ & 0.9988 \\
\hline 7 & 1 & 9 & $3.86 \mathrm{E}-02$ & 0.99871 \\
\hline 8 & 1 & 10 & $3.11 \mathrm{E}-02$ & 0.99881 \\
\hline 9 & 1 & 11 & $2.92 \mathrm{E}-02$ & 0.99878 \\
\hline 10 & 1 & 12 & $1.32 \mathrm{E}-02$ & 0.99879 \\
\hline 11 & 2 & 3 & 0.038648 & 0.99855 \\
\hline 12 & 2 & 4 & 0.029432 & 0.99879 \\
\hline 13 & 2 & 5 & 0.032531 & 0.99879 \\
\hline 14 & 2 & 6 & 0.028548 & 0.99882 \\
\hline 15 & 2 & 7 & 0.029277 & 0.99882 \\
\hline 16 & 2 & 8 & 0.036884 & 0.99863 \\
\hline 17 & 2 & 9 & 0.032666 & 0.99886 \\
\hline 18 & 2 & 10 & 0.032203 & 0.99883 \\
\hline 19 & 2 & 11 & 0.029799 & 0.99887 \\
\hline 20 & 2 & 12 & 0.031437 & 0.99885 \\
\hline
\end{tabular}

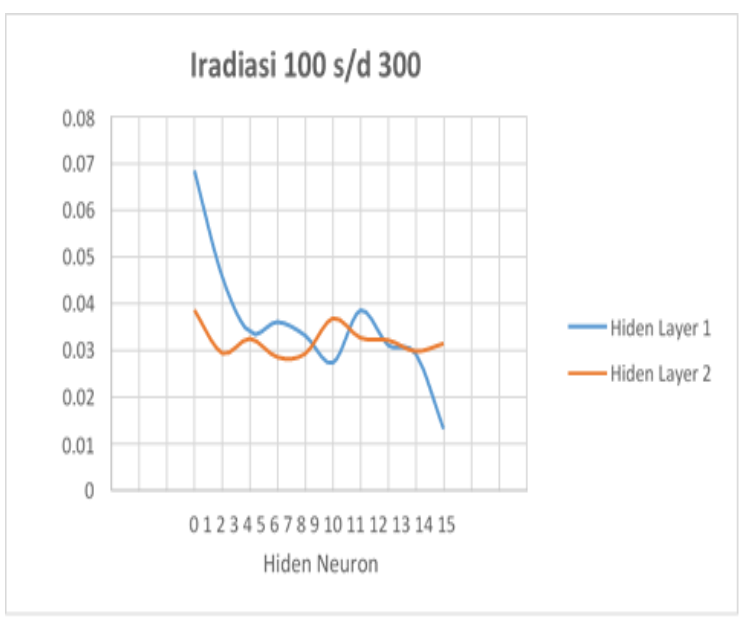

Gambar 19. Kurva Eror terhadap Hidden Neuron pada 1 iradiasi

Pada pengujian untuk 3 radiasi dari tabel 6 dan gambar 19 juga terlihat bahwa hasil terbaik adalah pada hidden layer 1, neuron 12, dimana memiliki nilai Mse sebesar 1.32E-02 dengan reggression 0.99879. Untuk hasil perbandingan antar kurva MPP Aktual dan MPPE dapat terlihat pada gambar 20 dibawah ini.

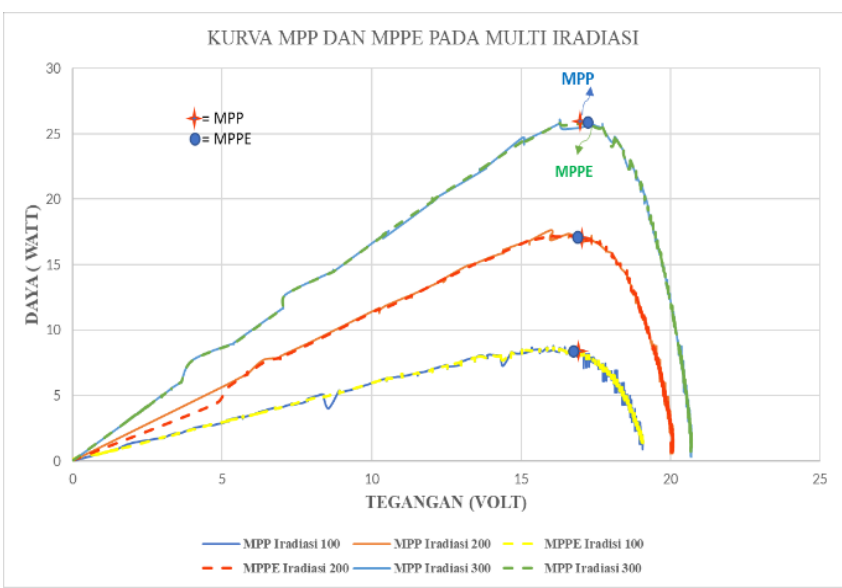

Gambar 20. Kurva MPP dan MPPE pada 3 iradiasi (Iradiasi 100-300).

Gambar kurva diatas merupakan hasil perbandingan pada 3 kondisi iradiasi, dimana ANN sudah sangat baik dalam melakukan estimasi untuk menentukan nilai MPP. Pada gambar 20 tersebut juga terlihat tidak ada perbedaan antara kurva I-V, P-V baik yg hasil pengukuran uniluminated maupun hasil estimasi pembelajaran dari ANN.

2.3 Hasil pengujian dengan multi iradiasi, hidden layer, neuron dan epoch. 


\section{Kesimpulan}

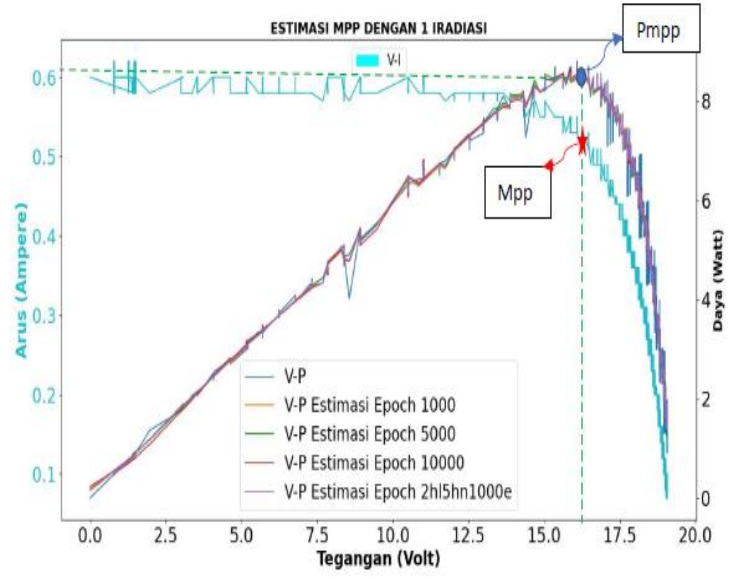

Gambar 21. Daya estimasi dan daya actual pada 1 iradiasi dengan beberapa hidden layer, neuron dan epoch

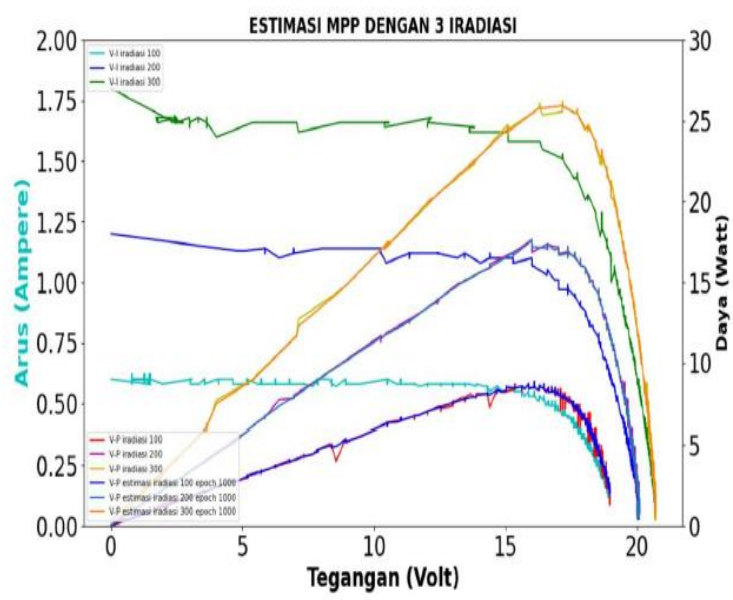

Gambar Gambar 22. Daya estimasi dan daya actual pada 3 iradiasi dengan beberapa hidden layer, neuron dan epoch

Gambar 21 dan 22 diatas terlihat bahwa kurva I-V dan P-V yang merupakan karakteristik dari panel surya sudah sesuai. Setelah dilakukan pengukuran dan training ANN di sofware MATLAB, telah mampu memberikan informasi tentang posisi daya maxsimum power point (MPP aktual) dan maximum power point Estimation (MPPE) pada beberapa kondisi iradiasi, dengan jumlah neuron serta epoch berbeda. Secara umum, pemodelan dengan menggunakan ANN ini sudah mampu untuk mendapatkan nilai Maxsimum Power Point Estimation (MPPE) dengan rata-rata selisih $=0.04$ point.

Makalah ini berisi tentang nilai daya yang dihasilkan oleh panel surya pada kondisi normal yang didapatkan dari energi surya. Berdasarkan hasil simulasi, kurva karakteristik P-V dari panel surya membuktikan bahwa metode FFBP Neural Network telah mampu mengestimasi nilai Maximum Power Point Estimation (MPPE) pada beberapa kondisi iradiasi, neuron dan epoch yang berbeda. Hasil dari simulasi MPPE dan MPP aktual didapatkan galat yang sangat kecil yaitu rata rata sebesar 0.04 point antara daya aktual dan daya estimasi.

\section{Ucapan Terima Kasih}

Ucapan terima kasih yang setinggi-tingginya kepada Beasiswa Pendidikan Pasca Sarjana Dalam Negeri (BPP-DN) untuk pembiayaan pendidikan dan riset yang diberikan, beserta kepada rekan-rekan Lab. Renewable Energy Politeknik Elektronika Negeri Surabaya (PENS) dan Politeknik Negeri Batam yang telah membantu sehingga riset ini terlaksana dengan baik.

\section{Daftar Pustaka}

[1]

[2]
BPPT Indonesia, Indonesia Energy OutLook 2017. Clean Energy Technology Development Initiatives. 2017.

M. Jedari and S. H. Fathi, “A New Approach for Photovoltaic Arrays Modeling and Maximum Power Point Estimation in Real Operating Conditions," IEEE Trans. Ind. Electron., vol. 0046, no. c, pp. 1-10, 2017, doi: 10.1109/TIE.2017.2711571.

J. Ma, H. Jiang, Z. Bi, K. Huang, X. Li, and H. Wen, "Maximum Power Point Estimation for Photovoltaic Strings Subjected to Partial Shading Scenarios," IEEE Trans. Ind. Appl., vol. PP, no. 1, pp. 1-13, 2018, doi: 10.1109/TIA.2018.2882482.

[4] X. Li, H. Wen, Y. Zhu, L. Jiang, Y. Hu, and W. Xiao, "A Novel Sensorless Photovoltaic Power Reserve Control With Simple RealTime MPP Estimation," IEEE Trans. Power Electron., vol. PP, no. c, p. 1, 2018, doi: 10.1109/TPEL.2018.2880461.

E. I. Batzelis, G. E. Kampitsis, and S. A Papathanassiou, "Power Reserves Control for PV Systems with Real-Time MPP Estimation via Curve Fitting," IEEE Trans. 
Sustain. Energy, vol. 3029, no. c, pp. 1-11, 2017, doi: 10.1109/TSTE.2017.2674693.

[6] X. Meng, Y. An, H. Wang, Q. Yao, and C. Liang, "Tracking the Maximum Power Point of Photovoltaic Power Generation Based on Self-coding Neural Network," in 2019 Chinese Control And Decision Conference (CCDC), 2019, pp. 592-597.

[7] S. Maharjan, J. C. H. Peng, and W. Xiao, "Improved Deterministic Real-Time Estimation of Maximum Power Point in Photovoltaic Power Systems," in IEEE GCC Conference and Exhibition, 2015, pp. 1-4.

[8] H. Wang and J. Shen, "Optimization Based on Mind Evolutionary Algorithm of Neural Networks used in PV Maximum Power Point Tracking," IEEE Access, vol. PP, no. 1, p. 1, 2018, doi: 10.1109/ACCESS.2018.2881888.

[9] S. Allahabadi, H. Iman-eini, and S. Farhangi, "Neural Network based Maximum Power Point Tracking Technique for PV Arrays in Mobile Applications," in 2019 10th International Power Electronics, Drive Systems and Technologies Conference (PEDSTC), 2019, pp. 701-706.

[10] M. Talbi, O. Makhlouf, N. Mensia, and H. Ezzaouia, "Maximum Power Point Tracking Control using Neural Network for Photovoltaic Systems," in 2019 10th International Renewable Energy Congress (IREC), 2019, pp. 1-6.

[11] A. Harrag, S. Messalti, and Y. Daili, "Innovative Single Sensor Neural Network PV MPPT," in 2019 6th International Conference on Control, Decision and Information Technologies (CoDIT), 2019, pp. 1895-1899.

[12] L. P. N. Jyothy and M. R. Sindhu, "An Artificial Neural Network Based MPPT Algorithm For Solar PV System,” in 2018 4th International Conference on Electrical Energy Systems (ICEES), 2018, pp. 375380 .

[13] A. Rubayet and M. M. A. Rahman, "SensorLess Solar Irradiance Estimation and Maximum Power Point Tracking Using Artificial Neural Network," in 2019 1st International Conference on Advances in Science, Engineering and Robotics Technology (ICASERT), 2019, pp. 1-5.

[14] S. H. Sunny, A. Naim, R. Ahmed, and K. Hasan, "Design and Simulation of Maximum Power Point Tracking of Photovoltaic System Using ANN," 2016, pp. $1-5$.

[15] J. Khanam and S. Y. Foo, "Neural Networks Technique for Maximum Power Point Tracking of Photovoltaic Array," in SoutheastCon 2018, 2018, pp. 1-4.
[16] J. Wu et al., "Maximum Power Point Tracking Algorithm for Laser Power Beaming Based on Neural Networks," in International Conference on Computer Technology, Electronics and Communication (ICCTEC), 2017, pp. 4-7, doi: 10.1109/ICCTEC.2017.00317.

[17] J. Mathew and G. Vincent, "Realtime Parameter Monitoring and Maximum Power Point Estimation of Solar Photovoltaic Array," in International Conference on Next Generation Intelligent Systems (ICNGIS), 2016, pp. 1-4.

[18] Tamrakar, V., Gupta, S. C., \& Sawle, Y. (2016). Study of characteristics of single and double diode electrical equivalent circuit models of solar PV module. International Conference on Energy Systems and Applications, ICESA, 312-317

[19] Amin mohammad Saberian, H. Hizam, M. A. M. Radzi, M. Z. A. Ab Kadir, dan Maryam Mirzaei," Modelling and Prediction of Photovoltaic Power Output Using Artificial Neural Networks," International Journal of Photoenergy, Volume 2014.

[20] Lei Xiao, Xiaohui Chen, dan Xinghui Zhang, "A Joint Optimization of Momentum Item and Levenberg-Marquardt Algorithm to Level Up the BPNN's Generalization Ability", Hindawi, Mathematical Problems in Engineering, Volume 2014, Article ID 653072, 10 pages. 